\title{
Effects of taxpayer compliance with taxpayer consciousness as intervening variable
}

\author{
Annas Lalo \\ Postgraduate School at Hasanuddin University of Indonesia, Makassar \\ Lecturer in Accounting, STIEM Bongaya Makassar \\ Made Sudarma \\ Professor in Accounting, Postgraduate School, \\ Brawijaya University of Indonesia \\ Kartini \\ Lecturer in Accounting, Postgraduate School, \\ Hasanuddin University of Indonesia, Makassar \\ Syamsuddin \\ Lecturer in Accounting, Postgraduate School, \\ Hasanuddin University of Indonesia, Makassar
}

\begin{abstract}
This study analyzes (1) the effect of tax authorities services on taxpayer awareness; (2) the effect of tax sanctions on taxpayer awareness; (3) the effect of tax audits on taxpayer awareness; (4) the effect of taxpayer awareness on mandatory compliance; (5) the effect of tax authorities services on taxpayer compliance; (6) the effect of sanctions on taxpayer compliance; (7) the effect of tax audits on taxpayer compliance; (8) the role of mediating the awareness of taxpayers in the influence of tax authorities services on taxpayer compliance; (9) the role of mediating the awareness of taxpayers in the effect of tax sanctions on taxpayer compliance; (10) the role of mediating taxpayer awareness in the effect of tax audits on taxpayer compliance. The population of this study is an individual taxpayer who performs free work registered at the North, South and West Makassar Primary Tax Office with 234.104 effective taxpayers still active. The research sample was 100 active taxpayers in the regional office of the directorate general of taxes in South Sulawesi. The sampling technique is purposive sampling. Data were analyzed using the Structural Equation Modeling method with the help of the Smart-PLS 3.0 program. The results of the study show that tax sanctions and tax audits have a direct or indirect effect on taxpayer compliance, while the services of tax authorities do not affect direct or indirect taxpayer compliance. The interesting result in this study is that the service of the tax authorities is not significant towards taxpayer compliance, but the positive influence fully mediates the effect of tax authority's services on taxpayer compliance through taxpayer awareness.
\end{abstract}

Keywords: Fiscal services, tax sanctions, tax examination, taxpayer awareness, and compliance

\section{INTRODUCTION}

The development cannot be implemented if the government does not have the availability of funds. The implications of non-implementation of development are that efforts to realize people's welfare are hampered. This shows that the availability of funds for the government is so important to facilitate the development process. One source of funding for the government comes from taxes. The Directorate General of Taxes of the Republic of Indonesia in 2016 noted 
that the global economic slowdown that occurred in 2015 did not prevent Indonesia from recording an economic growth of $4.7 \%$. The 2015 achievement is the foundation in setting the 2016 state budget. In 2016 the government set an ambitious budget target of Rp1,822 trillion, around $75 \%$ or Rp1,360 trillion derived from tax revenues. This figure has increased by $30 \%$ compared to the realization in 2015 (http://www.pajak.go.id/, 2016).

Related to the tax system, Indonesia applies a self assessment system, which is a system that gives responsibility to each taxpayer to register, calculate, pay and report their tax amount to the government itself. Thus, the amount of tax income of personal income is highly dependent on the level of compliance and awareness of taxpayers (Arum, 2012). On the other hand, a number of studies have found that the tendency to behave disobediently and dishonestly in behavior differs significantly across countries, non-compliance of taxpayers is a serious problem in many countries and most non-compliant taxpayers are associated with taxable income tax and delivery of tax reporting (Gneezy, 2005; Slemrod 2007; Mazar et al., 2008; Ariely, 2008; Kasper at al., 2015).

The low level of taxpayer compliance can be seen from the return rate associated with the delivery of the Notice. The following is a table that explains the level of taxpayer compliance at the Pratama Makassar Tax Office from 2013 to 2016.

Table 1. Taxpayer compliance at the Tax Offices (KPP) Pratama Makassar, Indonesia 2013-2016

\begin{tabular}{cccc}
\hline Years & $\begin{array}{c}\text { Number of Taxpayers } \\
(\mathrm{a})\end{array}$ & $\begin{array}{c}\text { Annual Notification } \\
\text { Letter (SPT) (b ) }\end{array}$ & $\begin{array}{c}\text { Compliance (b / ax } \\
100 \%)\end{array}$ \\
\hline 2013 & 187.533 & 110.623 & $58 \%$ \\
2014 & 200.486 & 113.708 & $56 \%$ \\
2015 & 211.617 & 108.974 & $51 \%$ \\
2016 & 223.194 & 110.079 & $49 \%$ \\
2017 & 234.104 & 108.781 & $46 \%$
\end{tabular}

Source: Tax Offices (KPP) Pratama Makassar (2017)

Based on Table 1. above, it can It is seen that from 2013 to 2017, the level of compliance of Individual Taxpayers at Makassar KPP Pratama declined. This certainly requires a study so that it does not occur protractedly. Therefore, these conditions provide motivation for conducting research on several factors that influence the level of taxpayer compliance at KPP Pratama Makassar.

Efforts to improve taxpayer compliance must lead to trust, awareness and socialization efforts with various programs, and not only can rely on the role of the Directorate General of Taxes (tax officials), but also the active role of the taxpayers themselves. The tax system reform has been carried out by the government, the taxation system from the official assessment system becomes a self-assessment system which is a tax collection system that raises issues relating to competence, honesty, trust, awareness, ability and readiness of taxpayers to accept the burden to calculate the tax amount payable and submit tax reports accurately (Palil et al., 2013). The relationship between taxpayer compliance and awareness in fulfilling tax obligations has been analyzed by several scholars (Saad, 2010; Sapiei, 2012; Sapiei \& Kasipillai, 2012). The role of sanctions and examinations in increasing tax compliance shows a positive influence (Alm J \& McKee, 2016), but it is different from the results of other undergraduate studies that tax audits have not made a big impact on private tax in Nigeria (Kennedy \& Anyaduba, 2014).

Other researchers examined taxpayer compliance, their findings provide evidence those fines, tax services (Fiscus) and tax awareness has a significant positive effect on tax compliance 
(Jatmiko, 2006; Muliari \& Setiawan, 2011). Tax audit, service quality and tax sanctions have a positive effect on taxpayer compliance, while service quality and tax sanctions do not affect taxpayer compliance (Masruroh, 2013). Tax law and tax sanctions have a major influence on tax compliance (Marvina, 2015).

Studies that rely on legal science perspectives are carried out by other researchers with the assumption that either through the threat of fear it is possible to be examined or then subject to taxation sanctions will force the taxpayer to comply with their obligations (Allingham \& Sandmo, 1972). Meanwhile, most of the research related to the relationship of increasing tax services to compliance was examined using a persuasive and cooperative approach between taxpayers and taxation authorities (Feld \& Frey, 2002; Alm et al., 2010; Vossler et al., 2011; De Simone, 2013; Hauptman et al., 2014). The effectiveness of this collaboration is also influenced by the calculation of profit and loss, both on the taxpayer's side and the tax authority. Therefore, persuasive efforts must be balanced with consistent law enforcement actions. Some other scholars examine the relationship between awareness and trust with the government (Wahl et al., 2010; Mas'ud et al., 2014; Doerrenberg, 2015; Hartl et al., 2015; Gangl et al., 2015). The influence of personal norms such as awareness is positively related to tax compliance (Coricelli et al., 2010; Christian \& Alm, 2014).

The discourse of the various research results has made it difficult to draw definite conclusions about how these factors affect taxpayer compliance. An objective method is needed to deduce various research results that may be saturated, but with inconsistent results. The research method using survey is a useful alternative to conclude various studies with inconsistent results. This research has added value in the form of a more comprehensive study compared to previous tax compliance studies, the factors that determine the level of tax compliance in Indonesia from various different points of view. This study also tries to describe the factors that have more influence on taxpayer compliance in Indonesia than other factors.

In general, the problems to which the answers are sought are important factors that cause the existence of several taxpayers who obediently pay taxes, but on the other hand there are also taxpayers who do not comply with paying taxes. One explanation of compliance with paying taxes is explained in a model called slippery slope framework (Kirchler et al., 2008; Prinz et al., 2014) as illustrated below:

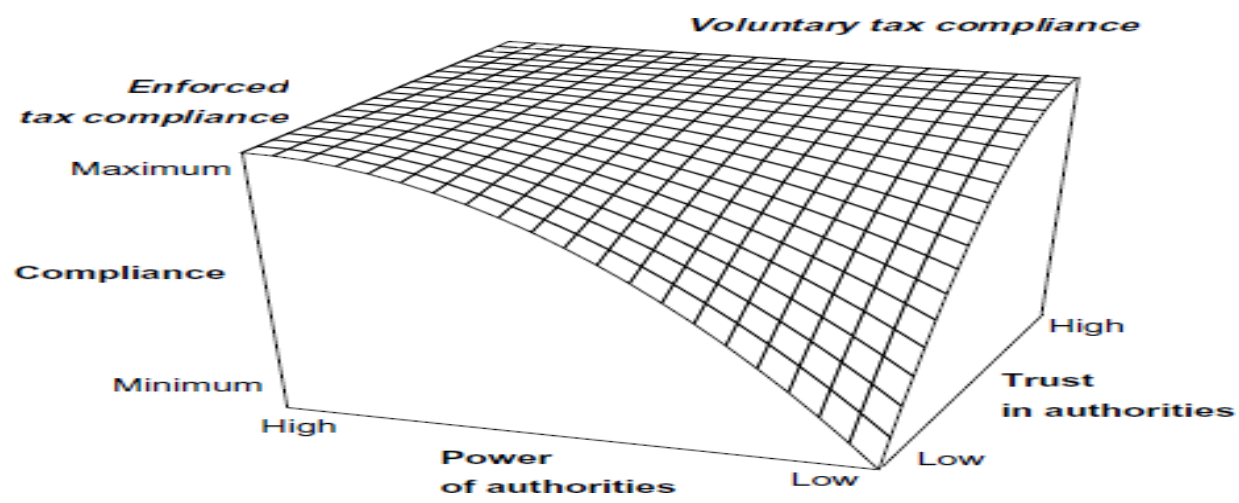

Figure .1 Slippery Slope Framwork

The framework it is explained that the willingness of people to pay taxes is because they consider that the cost (risk) of non-compliance will be very high (enforced tax compliance) or because of the awareness that paying taxes is indeed a duty as a citizen (voluntary tax compliance). Enforced tax compliance is affected by power of authorities, mainly because of 
the government's ability to enforce tax rules through aspects of inspection and tax sanctions. Voluntary tax compliance is influenced by the level of government service to taxpayers.

\section{Expected Utility Theory}

\section{LITERATURE REVIEW}

Expected Utility Theory (EUT) is a theory of decision making in situations of uncertainty (Harless, 1988; Moscati, 2016). This theory states that when there are several alternative possibilities of a risky event or uncertain outcome, one will make a decision based on the highest expected utility (EU). This EU value is the sum of the weighted utility rates calculated by summing the utility values of each choice after multiplying by probability or probability of occurrence (Mongin, 1997; Moscati, 2016). Social Contract Theory Rooted in the thoughts of Socrates \& Plato about the importance of avoiding coercion regarding relations between the state and citizens. Hobbes (1651) citen in Van Gelder (1998), popularizes what is then called social contract theory (SCT). This concept begins with the real conditions faced by humans, which initially lived and multiplied into many, but without the government and the laws that governed them. The risk of this situation is the risk of chaos, where there is a possibility that the rights possessed by someone will be violated by other people, without something preventing it (Friend, 2016). In addition to social contract theory (SCT), other theories used in building this research model refer to the Theory of planned bahaviour explains that a person's behavior is planned based on the information he receives or their perceptions of existing conditions or possibilities that will occur (Ajzen, 1991).

\section{Taxation services (Fiscus)}

Service is a level of excellence to fulfill customer desires.(Fiscal servicesTaxation services) are assessed based on the perception of taxpayers who compare expectations to receive services and actual experience of services received (Alm et al., 2010; Ayuba et al., 2015). There are five dimensions that determine service quality, namely: physical evidence, reliability, responsiveness, assurance of certainty and empathy (Parasuraman, 1985).

\section{Tax Penalties}

Penalties or sanctions are actions in the form of punishment given to people who violate the rules. Sanctions are deemed necessary so that rules and regulations are not violated (Allingham \& Sandmo 1972; Cho et al. 1996; Keller 1997; Arum, 2012). Indicators used in measuring tax sanctions use measurement of tax sanctions, namely: (a) Giving sanctions that are reasonable, (b) Imposing sanctions to educate taxpayers, (c) Tax sanctions to non-tolerant violators, (d) Imposing sanctions on taxes can be negotiated (Purnamasari et al., 2016; Muliari \& Setiawan, 2011).

\section{Tax audit}

Tax audit is a series of activities, namely collecting and processing data, data or evidence information carried out objectively and professionally in accordance with the standard compliance tax audit examination examination aimed at implementing the provisions contained in applicable tax laws (Muehlbacher et al., 2012; Dulleck et al., 2016). Tax audits are measured by (a) taxpayer accounting checks, (b) examination of records and documents, (c) interviews and physical testing, (d) cross-testing with third parties, (e) promising something with the examiner's decision (Suhendra, 2010)

\section{Taxpayer awareness}

Taxpayer awareness is the behavior or attitude of an object which involve assumptions and feelings and a tendency to act on the object (Li et al., 2018). Thus it can be said that the awareness of taxpayers in paying taxes is a taxpayer's behavior in the form of views or feelings 
involving knowledge, beliefs, and reasoning along with a tendency to act according to the rules given by the system and the tax provisions, (Riahi-Belkaoui, 2004; Muliari \& Setiawan, 2011; Christian \& Alm, 2014: Castro \& Scartascini, 2015). Taxpayers are said to have tax awareness if in accordance with the following: (a) Knowing taxation provisions, (b) Knowing tax functions, (c) Understanding taxation obligations, (d) Understanding tax functions (Muliari \& Setiawan, 2011).

\section{Taxpayer compliance}

Taxpayer compliance is the awareness of the public to fulfill their tax obligations (McKee et al., 2018), namely registering themselves to obtain the taxpayer's ID number (NPWP), submits an notification letter (SPT) with complete and correct calculation of all tax objects, paying taxes based on the actual amount and on time. Taxpayer compliance indicators, namely compliance with paying taxes, compliance making financial statements according to actual conditions and compliance with reporting Notification Letter (SPT). Indicators about taxpayer compliance are: (a) calculation of tax rates, (b) timely payments, (c) tax reporting, (d) obtaining a tax ID number (NPWP). These measurements develop measurements of taxpayer compliance (Bradley, 1994; Siahaan, 2012).

Based on the description above, the conceptual framework of the research can be illustrated in the following figure:

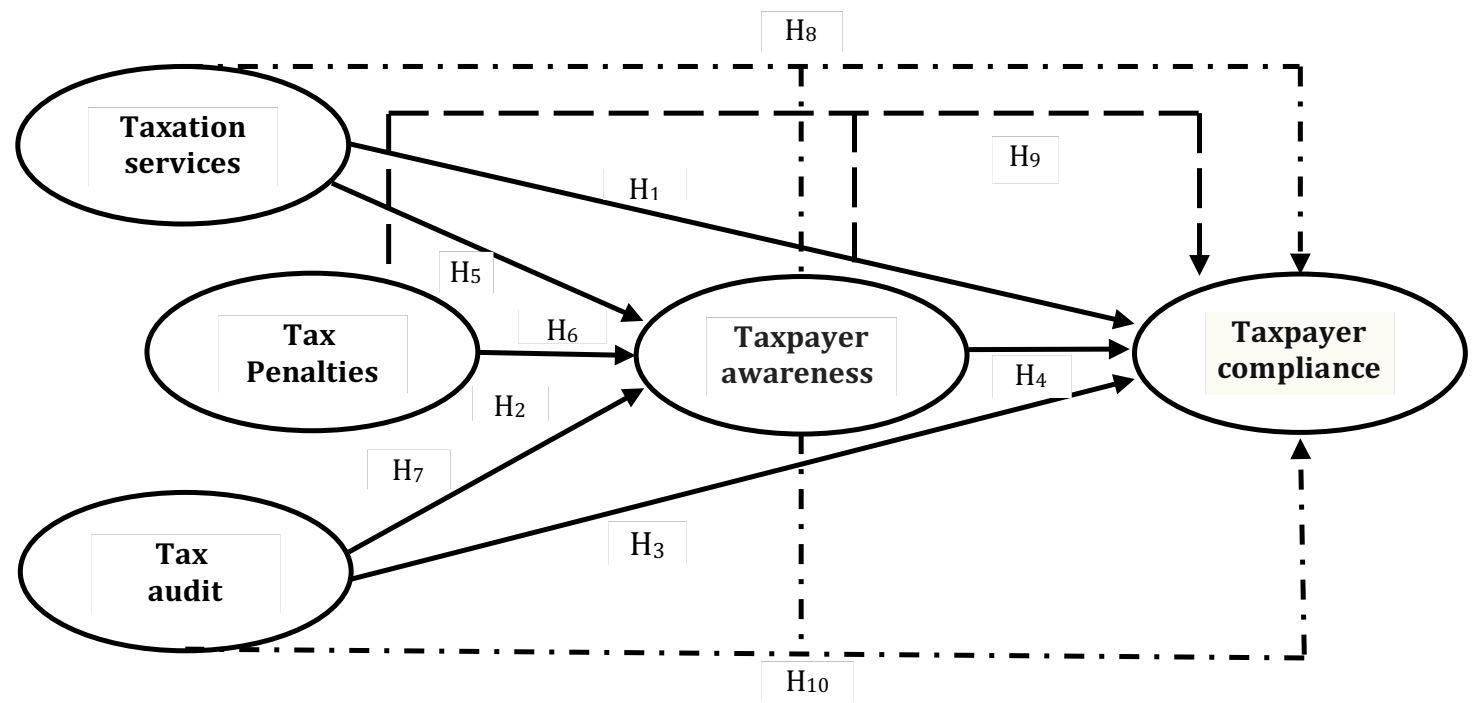

Figure 2. Research Framework

\section{Tax services (fiscus) affects on the taxpayer's compliance $\left(\mathrm{H}_{1}\right)$}

One of the factors, namely normative beliefs related to tax services (Taxation services (Fiscus)), that is when going to do something, individuals will have beliefs about normative expectations from others and motivation to fulfill those expectations and with good service from tax officers, an efficient and effective taxation system, as well as tax counseling that motivates taxpayers to obey taxes, will make taxpayers have confidence or choose tax compliance. The results of previous studies provide evidence that tax services (Taxation services (Fiscus)) have a positive effect on taxpayer compliance (Jatmiko, 2006; Muliari \& Setiawan, 2011).

\section{Tax penalties effects on the taxpayer's compliance $\left(\mathrm{H}_{2}\right)$}

The perspective of the law or the enforcement approach, Allingham \& Sandmo (1972) begin by assuming that the threat of sanctions, both through the threat of fear of the possibility of being 
examined and then subject to taxation sanctions will force the taxpayer to comply with their obligations.

\section{Tax audits effects on the taxpayer's compliance $\left(\mathrm{H}_{3}\right)$}

Enforced tax compliance is affected by power of authorities, mainly because of the government's ability to enforce tax rules through aspects of tax audit. In general, the role of inspection in increasing tax compliance shows a positive influence, as shown in some previous studies (Kasper et al., 2015; Alm et al., 2016).

\section{Taxpayer awareness affects on the taxpayer's compliance $\left(\mathrm{H}_{4}\right)$}

Based on the belief subjective norm concept in planned behavior theory (TPB), the behavior of a taxpayer whether to comply or not in fulfilling his tax obligations, is influenced by the norms he believes in. These norms originate from the environment in which the taxpayer is located or originates which is often referred to as social norms (Ajzen, 1985).

\section{Tax services (fiscus) affects on the taxpayer's Awareness $\left(\mathrm{H}_{5}\right)$}

Taxpayers awareness in fulfilling the obligation to pay taxes depends on how tax officers provide the best quality service to taxpayers (Alm et al., 2012). Tax services can be associated with normative beliefs which are one of the factors of Theory of Planned Behavior. Normative beliefs explain when going to do something, individuals will have beliefs about normative expectations from others and motivation to fulfill those expectations.

\section{Tax penalties affects on the taxpayer's Awareness $\left(\mathrm{H}_{6}\right)$}

The use of social contract theory (SCT) and the slippery slope framework explains that besides enforced tax compliance, voluntary tax compliance also plays an important role in the success of tax collection (Benk et al., 2012; Gangl et al., 2015). Moreover, if the system used is asystem self-assessment, where the WP is given the trust to calculate, calculate, pay and then report the tax owed. Conclusions that are not much different also appear in various other studies (Kastlunger et al., 2013; Kogler et al., 2013; Damayanti et al., 2015).

\section{Tax audit affects on the taxpayer's Awareness $\left(\mathrm{H}_{7}\right)$}

Expected Utility Theory (EUT) is a theory of decision making in uncertain situations (Harless, 1989; Moscati, 2016). This theory states that when there are several alternative possibilities of a risky event or uncertain outcome, one will make a decision based on the expected utility (EU) highest. Examination is the obedience or awareness of taxpayers in carrying out asystem selfassessment that is filling, calculating, calculating, collecting, cutting, and reporting all tax obligations in accordance with applicable tax law regulations (Marvina, 2015).

\section{Tax services (fiscus) effect on taxpayer's compliance: Taxpayer awareness as an intervening variable $\left(\mathrm{H}_{8}\right)$}

Based on the social contract theory, if the taxpayer has a perception that the government is positive, such as by providing good service to taxpayers so that it makes taxpayers easy to carry out their obligations, will encourage taxpayers to be aware of doing accordingly by complying with their tax payment obligations. This is also in accordance with what was stated by Alm et al. (2012), that tax authorities have often treated taxpayers as criminals who must be monitored and punished if they violate.

\section{Tax penalties effect on taxpayer's compliance: Taxpayer awareness as an intervening variable $\left(\mathbf{H}_{9}\right)$}

Tax penalties or tax sanctions also encourage people to be more obedient, then using expected utility theory, the amount of tax sanctions that will be imposed on tax evaders will also prevent 
taxpayers from disobedient behavior. Some researchers confirm a positive relationship between the amount of sanctions and compliance behavior of taxpayers. Doran (2009) based on a study of tax behavior in America concluded that tax sanctions not only encourage tax compliance, but also tax sanctions determine the standard of behavior that the law is enforced against taxpayers.

\section{Tax audits effect on taxpayer's compliance: Taxpayer awareness as an intervening variable (H10)}

Theoretically, as explained by expected utility theory, the possibility that someone will be examined will cause concern for him. Therefore, the higher a person's concern is to be examined, the lower his desire to do tax evasion. According to Alm et al. (2012), individual taxpayers often seem to be too worried about the possibility of being examined, even though data from various countries shows that the examination coverage ratio on average is low. Several other studies are also in line with the theory, where examinations will reduce the desire of taxpayers to embezzle taxes (Alm et al., 2012; Kastlunger et al., 2009; Muehlbacher et al., 2016).

\section{METHODS}

This study uses a scientific approach, which uses theoretical structures to form hypotheses and use facts or empirical data to test hypotheses and draw conclusions. The population of this study is individual taxpayers who carry out free work recorded at Tax Offices (KPP) Pratama Makassar (KPP Pratama (North), KPP Pratama (South), and KPP Pratama West Makassar). Whose status is still active, until January 2017 there was 234,104 effective taxpayers?

The determination of which individual taxpayer sample to choose is to use a purposive sampling method with the type of sample selection based on consideration the judgment sampling, which is a type of sample selection that is not random whose information is obtained using certain considerations generally adjusted to the objectives or research problems (Indriantoro \& Supomo, 2013). The criteria of the sample used in this study refer to Hair at al. (2010), which states that the minimum number of samples that must be taken is 15 to 20 times the number of variables used. The number of variables used in this study is 5 variables so that the minimum number of samples that must be taken is 5 X $20=100$

\section{Descriptive Statistics}

\section{RESULTS AND DISCUSSION}

In this study all constructs will be measured by at least four indicators with question items. Some of the criteria used to measure the reliability of a construct are the coefficient of Alpha Cronbach reliability, the coefficient of composite reliability and the proportion of extracted variance. The unidimensionality as a tool of reliability analysis and construct validity (Anderson \& Gerbing, 1988). A construct will be considered reliable if the Cronbach Alpha coefficient value at least 0.6 . Unidimensionality can also be measured by the convergent validity and reliability of the Bentler-Bonnet delta (Sjahruddin \& Sudiro, 2013; Sekaran, 2014).

Descriptive statistics provide a description or descriptive of a data that is seen from the minimum, maximum, average, and standard deviation values as follows: 
Table 1. Descriptive Statistics

\begin{tabular}{lccccc}
\hline & $\mathrm{N}$ & Minimum & Maximum & Mean & Std. Deviation \\
\hline Tserv & 100 & 12.00 & 20.00 & 17.30 & 2.022 \\
Tpenlt & 100 & 16.00 & 25.00 & 21.28 & 2.256 \\
Taud & 100 & 12.00 & 20.00 & 16.98 & 2.127 \\
Tawars & 100 & 15.00 & 20.00 & 17.70 & 1.772 \\
Tcompl & 100 & 13.00 & 20.00 & 17.12 & 1.976 \\
\hline
\end{tabular}

The construct of the taxation services (Fiscus) indicates the value of the minimum score 12 and score a maximum value of 20 . The average value for the construct of compliance services tax of $17.30>$ standard deviation of 2.022. This statistical result illustrates that respondents have the attitude that tax services (Taxation services) are a pleasant thing. Constructs of tax sanctions show a minimum score of 16 , and a maximum score of 25 . The average value for the tax sanction construct is 21.28> standard deviation of 2.256, this result illustrates that respondents have a high awareness of tax sanctions, whether individuals or groups agree tax compliance. In addition, this statistical value illustrates that respondents are motivated to adjust to compliance with tax obligations.

The examination construct shows a minimum score of 12 and a maximum score of 20 . The average value for the inspection construct is 16.98> standard deviation of 2.127. These statistical results illustrate that respondents have a strong level of awareness in tax audit behavior. The construct of awareness and tax compliance shows a minimum score of 15 and 13 , and a maximum awareness of 20 , and compliance 20 . The average value for the construct of awareness and compliance is 17.70,> standard deviation is 1.772 and 17.12> standard deviation is 1.976 . These statistical results illustrate that respondents have high compliance in fulfilling their functions, namely calculating, paying, and reporting the amount of tax owed.

\section{Evaluation Model}

This research model uses five constructs, namely tax service (Taxation services (Fiscus)), tax sanctions, tax audit, taxpayer awareness and tax compliance. Evaluation of the Smart-PLS model is done by evaluating the measurement model (outer model) and structural model (inner model).

\section{Convergent Validity Test}

The rule of thumb is commonly used to assess convergent validity, namely the value of loading factor $>0.7$ for studies confirmatory and the value of loading factors between 0.6-0.7 for studies exploratory and the value of AVE must be greater than 0.5 (Sholihin \& Ratmono, 2013: 16). Even for the initial research stage the value of the loading factor of $0.5-0.6$ is considered sufficient (Chin 1988; cited in Ghozali \& Latan, 2015: 74).

\section{Test of Discriminant Validity}

Measurement of discriminant validity by looking at the value of loading indicators to the measured construct is greater than loading other constructs (Sholihin \& Ratmono, 2013: 16).

\section{Testing the Structural Model (Inner Model)}

Testing the structural model (inner model) is done to measure the level of variation in changes in exogenous constructs towards endogenous constructs (Jogiyanto, 2011: 72). The structural model in PLS was evaluated using R-square $\left(\mathrm{R}^{2}\right)$ for endogenous variables. 
Table. 2 R-Square

\begin{tabular}{lcc}
\hline Construct & $R$-Square & R-Square Adjusted \\
\hline Taxpayer awareness & 0.223 & 0.199 \\
Taxpayer compliance & 0.266 & 0.235 \\
\hline
\end{tabular}

\section{Direct effect}

Direct effect is the influence that is directly measured from one variable to another. There are seven direct influences that can be tested in this study which are shown in following the table.

Table 3. Hypothesis testing (direct effect)

\begin{tabular}{llcccl}
\hline & Hypothesis & $\begin{array}{c}\text { Original } \\
\text { Sample }\end{array}$ & T-Statistics & P-Values & Decision \\
\hline $\mathrm{H}_{1}$ & Tserv $\rightarrow$ Tcompl & 0.076 & 0.728 & 0.467 & Rejected \\
$\mathrm{H}_{2}$ & Tpenlt $\rightarrow$ Tcompl & 0.212 & 2.161 & 0.031 & Accepted \\
$\mathrm{H}_{3}$ & Taud $\rightarrow$ Tcompl & 0.215 & 2.254 & 0.025 & Accepted \\
$\mathrm{H}_{4}$ & Tawars $\rightarrow$ Tcompl & 0.244 & 2.481 & 0.013 & Accepted \\
$\mathrm{H}_{5}$ & Tserv $\rightarrow$ Tawars & 0.011 & 0.110 & 0.913 & Rejected \\
$\mathrm{H}_{6}$ & Tpenlt $\rightarrow$ Tawars & 0.378 & 4.407 & 0.000 & Accepted \\
$\mathrm{H}_{7}$ & Taud $\rightarrow$ Tawars & 0.228 & 2.424 & 0.016 & Accepted \\
\hline
\end{tabular}

Table 3 shows the results of tests using the data processing program Smart-PLS. There are seven hypotheses of direct influence tested in this study. As shown in the table, there are two hypotheses of the direct effect of rejecting (H1 \& H5) t-statistical value $(t<1.96)$ at an alpha level of $5 \%$ with positive coefficient values of 0.076 and 0.011 .

\section{Indirect effect}

Indirect influence is a measured influence of one variable (in this research used by $\mathrm{X}_{1}, \mathrm{X}_{2}$ and $\mathrm{X}_{3}$ ) on the variable taxpayer compliance $(\mathrm{Y})$ through the mediator variable $(\mathrm{Z})$, namely the awareness of the taxpayer. In testing the mediation effect, the output of significant test parameters is seen in the total effect table. If the t-statistic value on taxpayer awareness is $<1.96$, it is stated that it is not successful in mediating the effect of tax services (Fiscus) variable, tax sanction, and tax audit on the variable of taxpayer compliance. Conversely, if the value of t-statistic of taxpayer awareness variable> 1.96, it is stated that it is successful in mediating the effect of tax services (Fiscus) variables, tax sanctions, and checks on variable tax compliance. There are three indirect influences tested in this study, but research shows that H8 is rejected because statistically the $t$ value of 0.106 is smaller than the $t$-value of statistics $(t$ $<1.96)$. The following is the value of the total indirect effect with the influence of mediation in this study:

Table .4 Hypotheses testing (Indirect effect)

\begin{tabular}{llcccc}
\hline & Causality relationship & $\begin{array}{c}\text { Original } \\
\text { Sample }\end{array}$ & T-Statistics & P Values & Decision \\
\hline $\mathrm{H}_{8}$ & Tserv $\rightarrow$ Tawars $\rightarrow$ Tcompl & 0.003 & 0.106 & 0.916 & Rejected \\
$\mathrm{H}_{9}$ & Tpenlt $\rightarrow$ Tawars $\rightarrow$ Tcompl & 0.092 & 1.988 & 0.047 & Accepted \\
$\mathrm{H}_{10}$ & Taud $\rightarrow$ Tawars $\rightarrow$ Tcompl & 0.056 & 2.160 & 0.031 & Accepted \\
\hline
\end{tabular}

First, the hypothesis $8\left(\mathrm{H}_{8}\right)$ stated the tax services (fiscus) has a positive effect on tax compliance through taxpayer awareness. The test results show that the statistic $t$-value of the variable shows insignificant results, which is equal to $0.106<1.96$. Based on table 5 , it can be seen that the beta value $(\beta)$ shows a positive value of 0.003 . So it can be concluded that the taxpayers awareness strengthens the positive influence of tax services on taxpayer compliance, 
but based on the results of statistical tests it can be concluded that the eighth hypothesis is rejected, which shows a statistical $t$ value of 0.103 smaller than the value $(t<1.96)$.

Second, hypothesis $9\left(\mathrm{H}_{9}\right)$ states that tax penalties have a positive effect on taxpayer compliance through taxpayer awareness. The test results show that the statistic $t$-value of the variable shows significant results, which is equal to 1.988 , greater than $(>1.96)$. Based on table 5.13 , it can be seen that the beta value $(\beta)$ shows a positive value of 0.092 . So it can be concluded that tax penalties strengthen the positive influence of taxpayer awareness on taxpayer compliance, based on these results it can be concluded that the ninth hypothesis is accepted, which shows a statistical t value of 1.988 greater than the t-value $(>1.96)$.

Third, hypothesis $10\left(\mathrm{H}_{10}\right)$ states that tax audit has a positive effect on taxpayer compliance through taxpayer awareness. The test results show the statistic $\mathrm{t}$-value of the variable shows a significant result, which is equal to 2.160 , greater than $(>1.96)$. Based on table 5.13 , it can be seen that the beta value $(\beta)$ shows a positive value of 0.056 . So it can be concluded that the taxpayers awareness reinforces the positive influence of tax audits on taxpayer compliance, and based on these statistical results it can be concluded that the tenth hypothesis is accepted, which shows a statistical $t$ value of 2.160 greater than the value $(t>1.96)$.

\section{CONCLUSIONS}

The main conclusion of this study provides information that the role of tax authorities, tax sanctions, tax audits, and awareness of taxpayers in improving taxpayer compliance proved effective. Similarly, the role of tax authorities, tax sanctions, and tax audits also proved effective in increasing taxpayer awareness. Other findings of this study inform that the service of tax authorities has not provided benefits to the awareness of taxpayers, and awareness of taxpayers as an intervening variable does not provide a significant influence on increasing tax compliance.

\section{References}

Ajzen, I. (1985). From intentions to actions: A theory of planned behavior. In J. Kuhl \& J. Beckman (Eds.), Action control: From cognition to Heidelberg's behavior: Springer

Ajzen, I. (1991). The theory of planned behavior. Organizational behavior and human decision processes, 50 (2), 179-211.

Allingham, MG, \& Sandmo, A. (1972). Income tax evasion

Alm, J., Bruner, DM, \& McKee, M. (2016). Honesty or dishonesty of taxpayer communications in an enforcement regime. Journal of Economic Psychology, 56, 85-96.

Alm, J., Cherry, T., Jones, M., \& McKee, M. (2010). Taxpayer information assistance services and tax compliance behavior. Journal of Economic Psychology, 31 (4), 577-586.

Alm, J., Kirchler, E., \& Muehlbacher, S. (2012). Combining Psychology and Economics in the Analysis of Compliance: From Enforcement to Cooperation1. Economic Analysis and Policy, 42 (2), 133-151.

Anderson, JC, \& Gerbing, DW (1988). Structural equation modeling in practice: A review and recommended twostep approach. Psychological bulletin, 103 (3), 411.

Ariely, D., Kamenica, E., \& Prelec, D. (2008). Man's search for meaning: The case of Legos. Journal of Economic Behavior \& Organization, 67 (3-4), 671-677.

Arum, HP (2012). The effect of taxpayer awareness, tax authorities services, and tax sanctions on taxpayer compliance of individuals who carry out business activities and free work (study in KPP Pratama Cilacap Area) (Doctoral dissertation, Faculty of Economics and Business).

Ayuba, A., Saad, N., \& Ariffin, ZZ (2015). The influence of work family conflict and fuel subsidy removal on tax compliance: A proposed framework for small and medium enterprises.

Belkaoui, AR (2011). International relationship between tax compliance and selected determinants of tax morale. Journal of International Accounting, Auditing and Taxation, 13 (2), 135-143. 
Benk, S., Budak, T., \& Cakmak, AF (2012). Tax Professional Perceptions of Tax Fairness: Survey Evidence In Turkey. International Journal of Business and Social Science, 3 (2).

Bradley, CF (1994). An empirical investigation of factors: Corporate tax compliance behavior (Doctoral dissertation, University of Alabama).

Castro, L., \& Scartascini, C. (2015). Tax compliance and enforcement in evidence evidence from a field experiment. Journal of Economic Behavior \& Organization, 116, 65-82.

Cho, J., Linn, SC, \& Nakibullah, A. (1996). Tax evasion with penalty costs and penalty renegotiation. Southern Economic Journal, 172-190.

Christian, RC, \& Alm, J. (2014). Empathy, sympathy, and tax compliance. Journal of economic psychology, 40, 6282.

Coricelli, G., Joffily, M., Montmarquette, C., \& Villeval, MC (2010). Cheating, emotions, and rationality: an experiment on tax evasion. Experimental Economics, 13 (2), 226-247.

Damayanti, TW, Sutrisno, T., Subekti, I., \& Baridwan, Z. (2015). The role of taxpayer's perception of government and society to improve tax compliance. Accounting and Finance Research, 4 (1), 180.

De Simone, L., Sansing, RC, \& Seidman, JK (2013). Tax compliance programs mutually beneficial? The Accounting Review, 88 (6), 1971-1991.

Doerrenberg, P. (2015). Does the use of tax revenue matter for tax compliance behavior? Economics Letters, 128, 30-34.

Doran, M. (2009). Tax penalties and tax compliance. Harv. J. on Legis., 46, 111.

Dulleck, U., Fooken, J., Newton, C., Ristl, A., Schaffner, M., \& Torgler, B. (2016). Tax compliance and psychic costs: behavioral experimental evidence using a physiological marker. Journal of Public Economics, 134, 9-18.

Feld, LP, \& Frey, BS (2002). Trust breeds trust: How taxpayers are treated. Economics of Governance, 3 (2), 87-99.

Friend, C. (2016). Social contract theory. Retrieved November 10, 2016, from http://www.iep.utm.edu/soccont/.

Gangl, K., Hofmann, E., \& Kirchler, E. (2015). Interaction with taxpayers: A conception of compliance in social dilemmas by power and trust. New ideas in psychology, 37, 13-23.

Ghozali, I., \& Latan, H. (2015). Partial least squares: Concepts, techniques and applications use the SmartPLS 3.0 program for empirical research. Semarang: UNDIP Publishing Agency.

Gneezy, U. (2005). Deception: The role of consequences. American Economic Review, 95 (1), 384-394.

Hair, JF (2010). Black, WC, Babin, BJ, \& Anderson, RE (2010). Multivariate data analysis, 7.

Harless, DW (1989). Three essays on the rational requirements of expected utility theory.

Hartl, B., Hofmann, E., Gangl, K., Hartner-Tiefenthaler, M., \& Kirchler, E. (2015). Does the Sole Description of a Tax Authority Affect Tax Evasion? - The Impact of Described Coercive and Legitimate Power. PloS one, 10 (4), e0123355.

Hauptman, L., Horvat, M., \& Korez-Vide, R. (2014). Improving tax administration services as a factor of tax compliance: The case of tax audit. Lex localis, 12 (3), 481-501.

Indriantoro, Nur. \& Supomo, Bambang. (2013). Business Research Methodology for Accounting \& Management. Yogyakarta: BPFE.

Jatmiko, AN (2006). The Influence of Taxpayer Attitudes on the Implementation of Penal Sanctions, Tax Services and Tax Awareness on Taxpayer Compliance (Empirical Study of Individual Taxpayers in the City of Semarang) (Doctoral dissertation, Diponegoro University Post Graduate Program).

Jogiyanto, HM (2011). Business Research Methodology (Fourth Edition). BPFE. Yogyakarta.

Kasper, M., Kogler, C., \& Kirchler, E. (2015). Tax policy and the news: An empirical analysis of taxpayers' perception of tax-related media coverage and its impact on tax compliance. Journal of Behavioral and Experimental Economics, 54, 58-63.

Kastlunger, B., Lozza, E., Kirchler, E., \& Schabmann, A. (2013). Powerful authorities and trusting citizens: The Slippery Slope Framework and tax compliance in Italy. Journal of Economic Psychology, 34, 36-45.

Keller, CE (1997). An experimental investigation of how ethical orientations, tax rates, penalty rates, and audit rates affect tax compliance decisions. 
Kennedy, PM, \& Anyaduba, JO (2014). The impact of the tax audit on tax compliance in Nigeria. International Journal of Business and Social Science, 5 (9).

Kirchler, E., Hoelzl, E., \& Wahl, I. (2008). Enforced versus voluntary tax compliance: The "slippery slope" framework. Journal of Economic Psychology, 29 (2), 210-225.

Kogler, C., Batrancea, L., Nichita, A., Pantya, J., Belianin, A., \& Kirchler, E. (2013). Trust and power as a determinant of tax compliance: Testing the assumptions of the slippery slope framework in Austria, Hungary, Romania and Russia. Journal of Economic Psychology, 34, 169-180.

Li, Z., Zheng, W., Meng, Q., \& Jin, S. (2018). The impact of government subsidy and tax policy on the competitive decision-making of remanufacturing supply chains. International Journal of Sustainable Engineering, 1-12.

Marvina, Ramdhan (2015). The effect of tax law and administration sanction compliance taxpayer. Journal of Survey on Individual Taxpayers in KPP Pratama Bandung Karees

Mas'ud, A., Manaf, NAA, \& Saad, N. (2014). Do trust and power moderate each other in relation to tax compliance? Procedia-Social and Behavioral Sciences, 164, 49-54.

Masruroh, S. (2013). Effect of Employee Benefits, Taxpayer Understanding, Service Quality, Tax Sanctions Against Taxpayer Compliance (Empirical Study on OP WP in Tegal Regency). Diponegoro Journal of Accounting, 435-449.

Mazar, N., Amir, O., \& Ariely, D. (2008). The dishonesty of honest people: A theory of self-concept maintenance. Journal of marketing research, 45 (6), 633-644.

McKee, M., Siladke, C. A., \& Vossler, C. A. (2018). Behavioral dynamics of tax compliance when taxpayer assistance services are available. International Tax and Public Finance, 25(3), 722-756.

Mongin, P. (1997). Expected utility theory. Handbook of economic methodology, 342350.

Moscati, I. (2016). Retrospectives: how came economists to accept expected utility theory: the case of samuelson and savage. Journal of economic perspectives, 30 (2), 219-36.

Muehlbacher, S., Mittone, L., Kastlunger, B., \& Kirchler, E. (2012). Uncertainty resolution in tax experiments: Why waiting for an audit increases compliance. The Journal of Socio-Economics, 41 (3), 289-291.

Muliari, NK, \& Setiawan, PE (2011). Effect of perceptions of taxation sanctions and taxpayer awareness on compliance Individual taxpayer reporting in the pratama tax service office in East Denpasar Accounting and Business Scientific Journal.

Palil, MR, Akir, MR, \& Ahmad, WF (2013). The perception of tax on tax knowledge and tax education with level of tax compliance: A study of the influences of religiosity. ASEAN Journal of Economics, Management and Accounting, 1 (1), 118-129.

Parasuraman, A., Zeithaml, VA, \& Berry, LL (1985). A conceptual model of service quality and its implications for future research. the Journal of Marketing, 41-50.

Prinz, A., Muehlbacher, S., \& Kirchler, E. (2014). The slippery slope framework on tax compliance: An attempt to formalization. Journal of Economic Psychology, 40, 20-34.

Purnamasari, A., Pratiwi, U., \& Sukirman, S. (2018). Influence of Understanding, Tax Sanctions, Level of Trust in Government and Law, and Nationalism Against Compliance with Taxpayers in Paying PBB-P2 (Study on PBB-P2 Taxpayers in Banjar City). Journal of Accounting and Auditing, 14 (1), 22-39.

Riahi-Belkaoui, A. (2004). International relationship between tax compliance and selected determinants of tax morale. Journal of international accounting, auditing and taxation, 13 (2), 135-143.

Saad, N. (2010). Fairness Perceptions and Compliance Behavior: The Case of Salaried Taxpayers in Malaysia after the Implementation of the Self-Assessment System. eJournal of Tax Research, 8 (1).

Saad, N. (2012). Perceptions of Tax Fairness and Tax Compliance Behavior: A Comparative Study (Equivalent Perception and Signs of Compliance with Excise: A Comparative Study). Management Journal (UKM Journal of Management), 36.

Sapiei, NS (2012). External Tax Professionals 'Perception of the Corporate Taxpayers' Compliance Costs and Behavior under the Self-Assessment System. Monash University Sunway Campus, Malaysia, Kuala Lumpur

Sekaran, Uma. (2014). Research Method for Business (Research Methods for Business). Book 1 Issue 4. Jakrta: Salemba Four.

Sholihin, M., \& Ratmono, D. (2013). SEM-PLS Analysis with WarpPLS 3.0 for Nonlinear Relations in Social and Business Research. Yogyakarta: Andi Publisher. 
Siahaan, FO (2012). The influence of tax fairness and communication on voluntary compliance: trust as an intervening variable. International Journal of Business and Social Science, 3 (21).

Sjahruddin, H., \& Sudiro, A. A. (2013). Organizational justice, organizational commitment and trust in manager as predictor of organizational citizenship behavior. Interdiciplinary J. of contemporary Res. Bus.(IJCRB), 4(12), 133141.

Slemrod, J. (2016). Tax compliance and enforcement: New research and its policy implications.

Suhendra, ES (2010). Effect of Corporate Taxpayer Compliance Level on Increasing Income Tax Receipts. Accounting journal.

Van Gelder, T. (1998). The dynamical hypothesis in cognitive science. Behavioral and brain sciences, 21 (5), 615628.

Vossler, CA, McKee, M., \& Jones, M. (2011). Tax information services are available on tax reporting behavior.

Wahl, I., Kastlunger, B., \& Kirchler, E. (2010). Tax compliance trusts and authorities: An empirical analysis of the "Slippery Slope Framework". Law \& Policy, 32 (4), 383-406. 